\title{
The influence of the environment on microbiological parameters of snails' meat
}

\author{
I. Danilova ${ }^{1}$, T. Danilova² \\ ${ }^{1}$ National Scientific Center "Institute of Experimental and Clinical Veterinary Medicine" 83, Pushkinska Str., Kharkiv, 61023, \\ Ukraine. \\ ${ }^{2}$ Kharkiv State Zooveterinary Academy 1, Akademichna Str., Mala Danylivka, Dergachi district, Kharkiv region, 62341, Ukraine. \\ E-mail: irrulik@meta.ua
}

Received: 12.06.2019. Accepted: 08.07.2019

\begin{abstract}
Among the problems of hygiene of food products special attention is paid to the prophylaxis of human illnesses which occur as a result of the use of such quite exotic product as snails' meat that can be affected by microflora, as well as to the improvement of hygienical conditions of breeding, transporting and processing of meat. Microorganisms get to the organism of snails systematically and their presence confirms certain mechanism of infection of gastropods molluscs and in such way characterizes the object from the point of view of potential danger. Food product including snails' meat is a favourable medium for their development. In order to prevent the development of microorganisms it is necessary to minimize or to limit the influence of the factors of environment on the organism of snails. Air, soil and water belong to such factors. At certain conditions pathogenic microbes get to the intestines of snails from the environment and can penetrate to other organs and muscles. As a result, meat from such snails is of low quality and biodegradable.

It was determined in the conducted research that for snails breeding it is necessary to minimize negative influence of environmental factors of air, soil and water. In the premises where snails are kept when it is cold the amount of dust and consequently the amount of microorganisms depends on the way of premises cleaning, organiation of production process, application and efficiency of ventilation, etc.

Contamination of snails, and therefore, of prepared products by microflora leads not only to considerable economic loss but also can become a reason of getting of poisonous substances and pathogenic bacteria to the human organism that cause serious diseases which can be dangerous for life.
\end{abstract}

Keywords: Meat; snail; microbiological parameters; influence; environment

\section{Introduction}

The hygiene of snails and prophylaxis of diseases connected with the use of snail products depends on many factors of the environment including breeding, transporting, processing, storage, realization and natural factors of the environment. The process of control of snail product quality includes the observance of high hygienical standards during heat treatment and the storage.

The process of bacterial decay occurs when the temperature of the environment is over $25^{\circ} \mathrm{C}$. Microorganisms penetrate into snails' meat from intestines, mucus, and also from the places of their lesions.

Microflora that causes the decay of snails consists of proteolytic active microbes which belong to their natural microflora, and also of microbes which got there with new snails. Thus, it is important to take into consideration that transport containers, places of maintenance, technological lines during processing of snails, freezers and ice can be contaminated by microorganisms.

Under the influence of microorganisms deep breakdown of protein substances of snails with creation of stinking ones take place. These substances have toxic properties, for example, monoetilamin connections, hydrogen sulphide, indol, scatol, ammonia; formic, oxalic and butyric acids.

At the bacterial breakdown of proteins, proteins first break down to amino acids and deamination and decarboxylation of amino acids with creation of less complicated substances under the influence of specific enzymic systems of microorganisms take place (Masoumbeigi \& Tavakoli, 2017).

Meat is seeded with microorganisms both endogenously (when invertebrates are alive) and after the processing (Mikityuk \& Zhitenko, 1989). Besides contamination of meat when an animal is alive, it can occur as a result of the weakening of natural defence of snails (hypothermia, overheating, excessive starvation, aggregation) when microorganisms from the intestines spread throughout the organism.

Species composition of superficial microflora of snails' meat can be various and occasional. Mainly ground bacilli, clostridia, cocci, microorganisms of intestines, fungi are detected in such meat. Gradually microorganisms get into the meat and cause its spoilage aggregating in favourable conditions on the surface. Intensity of these processes depends on the temperature, relative humidity, degree of initial meat seeding. It is not always accompanied by simultaneous spread of sanitary model microorganisms that reduces the role of the latter considerably in terms of indexes of sanitary unfavourability (Klevakin \& Kartsev, 1986).

Microorganisms are widespread in nature. They are in air, soil, water and can easily penetrate into invertebrate molluscs.

Some amount of microorganisms is always in the atmosphere. They get into air from the surface of soil, with rising dust and also with tiny drops of moisture which are blown away from the aquatic surface.

Air without liquid water is not a favourable medium for development of microorganisms. Quantitative and qualitative composition of microflora of atmospheric air can change considerably depending on climatic conditions, seasons and other factors (Stella \& Bernardi, 2018). 
Air microflora has occasional composition. Most frequently there can be different micrococci, sarcina, bacteria spores, fungi or pathogens. Soil is abundantly inhabited by microorganisms. They find there necessary conditions for their development: food, moisture and defence from harmful influence of direct sunbeams and drying.

Soil microflora has various species of bacteria, actinomycetes, fungi, algae, and protozoa. Among bacteria there are putrid, oily acid bacteria that break down cellulose; nitrifying, denitrifying, nitrogen fixing bacteria, etc. There are also pathogens mainly spores bacteria. Therefore, contamination of soil by microorganisms is very dangerous (Koutsoumanis \& Stamatiou, 2006).

Composition of soil, physical properties, medium reaction, content of air and moisture, climatic conditions, season, ways of soil processing have a considerable influence on quantitative and qualitative composition of soil microflora.

Natural water always contains some amount of organic and mineral substances which can be used by microorganisms as nutrients. Natural water that is used for feeding and irrigation of snails can contain a big number of microorganisms, but qualitative and quantitative composition of microbes is extremely various.

First of all, in sanitary estimation of water special attention is paid to pathogenic microorganisms (Mikityuk \& Zhitenko, 1989).

Numerous pathogenic bacteria are kept in water for a long time, some of them even spread. Composition and amount of pathogens in water depends on chemical composition of water, degree of contamination by organic substances, season, weather, etc (Klevakin \& Kartsev, 1986).

At food enterprises engaged in meat processing water is used for production of wide range of products, for washing raw materials, machines, containers, etc. The use of water with a big number of microbes leads to excessive contamination of products. The presence of pathogens in water is very dangerous. Therefore, water used in food industry as well as drinking water must meet certain sanitary-hygenic standards (Mitichkin, 1966).

Thus, we can say that the influence of the environment is directly connected with microbiological parameters of meat.

\section{Purpose}

The purpose of this work was to determine basic microbiological parameters of standards of snails' meat from different regions of Ukraine and according to these data to determine the influence of environmental factors on the organism of snails. To achieve this purpose the following tasks were set:

1. to define microbiological parameters in the samples of snails' meat: MAOAM (mesophilic-aerobic and optional-anaerobic microorganisms), E. coli bacteria (coliforms), coagulase-positive staphylococcus (Staphylococcus aureus), Bacteria of Proteus family, pathogenic microorganisms, including salmonella and Listeria monocytogenes;

2. to analyze possible factors of influence on the organism of snails and microorganisms.

\section{Materials and methods}

Snails' meat of the species Helix aspersa muller and Helix pomatia was selected for the research. Snails of the first species were purchased at the farm "RAVLIK 2016", snails of the species Helix pomatia were gathered in different regions of Ukraine. Average samples of snails' meat were used in the research. Sample 1-meat of snails H. aspersa muller; Sample 2-meat of snails H. pomatia Kazatske village, Berislavsky district, Kherson region; sample 3-meat of snails H. pomatia Berezna village, Polonsky district, Khmelnytsky region; Sample 4-meat of snails $H$. pomatia Mala Danylivka village, Dergachi district, Kharkiv region.

The determination of microbiological parameters was carried out in accordance with the current normative documentation (DSTU 8446:2015, GOST 30518-97, GOST 10444.2-94, DSTU 7444:2013, DSTU EN 12824:2004, DSTU ISO 11290-1:2003, DSTU ISO 11290-2:2003) for research methods (Table 1).

Table 1. Normative documentation used in the research.

\begin{tabular}{ll}
\hline Parameter name, unit of measurement & ND for research methods \\
MAOAM KUO/g & DSTU 8446:2015 \\
$\begin{array}{l}\text { E. coli bacteria (coliforms) in 1.0 g } \\
\text { Coagulase-positive staphylococcus (S. aureus) in 1.0 g }\end{array}$ & GOST 30518-97 \\
Bacteria of Proteus family in 0.1 g KUO/g & GOST 10444.2-94 \\
$\begin{array}{l}\text { Pathogenic microorganisms, including salmonella, in 25.0 g } \\
\text { Listeria monocytogenes in 25.0 g }\end{array}$ & DSTU EN 12824:2004 \\
\hline
\end{tabular}

\section{Results}

We tested 4 samples of snails' meat from different regions of Ukraine according to microbiological parameters, the results of which are given in Table 2.

Table 2. Samples investigation of snails' meat from different regions of Ukraine according to microbiological parameters.

\begin{tabular}{|c|c|c|c|c|c|c|c|c|}
\hline Parameter name, & Sample $\mathbf{N}$ & & & & & & & \\
\hline unit of measurement & 1 & & 2 & & 3 & & 4 & \\
\hline MAOAM KUO/g & $2.1 \times 104$ & & $3.6 \times 104$ & & $8.0 \times 102$ & & $2.7 \times 104$ & \\
\hline E. coli bacteria (coliforms) in $1.0 \mathrm{~g}$ & $\begin{array}{l}\text { E. coli } \\
\text { detected }\end{array}$ & bacteria & $\begin{array}{l}\text { E. coli } \\
\text { detected }\end{array}$ & bacteria & $\begin{array}{l}\text { E. coli } \\
\text { detected }\end{array}$ & bacteria & $\begin{array}{l}\text { E. coli } \\
\text { detected }\end{array}$ & bacteria \\
\hline
\end{tabular}




\begin{tabular}{|c|c|c|c|c|}
\hline $\begin{array}{l}\text { Coagulase-positive staphylococcus (S. aureus) in } \\
1.0 \mathrm{~g}\end{array}$ & Undetected & Undetected & Undetected & Undetected \\
\hline Bacteria of Proteus family in $0.1 \mathrm{~g} \mathrm{KUO} / \mathrm{g}$ & Undetected & Undetected & Undetected & Undetected \\
\hline $\begin{array}{l}\text { Pathogenic microorganisms. including salmonella. } \\
\text { in } 25.0 \mathrm{~g}\end{array}$ & Undetected & Undetected & Undetected & Undetected \\
\hline Listeria monocytogenes in $25.0 \mathrm{~g}$ & Undetected & Undetected & Undetected & Undetected \\
\hline
\end{tabular}

Data from Table 2 show that in all four samples coagulase-positive staphylococci (S. aureus), bacteria of Proteus family, pathogenic microorganisms, including salmonella and Listeria monocytogenes were not detected. However, E. coli bacteria (coliforms) were detected and the results differed in the indexes of MAOAM.

Thus, according to our data, the smallest seeding has sample number 3 (Figure 1) by the index of MAOAM and by the above mentioned indexes and made up $8.0 \times 102$, that corresponds $H$. pomatia snails from Berezna village, Polonsky district, Khmelnitsky region. And the largest seeding according to all indexes was in sample 2 (Figure 2), that corresponds $H$. pomatia snails Kazatsky village, Beryslavsky district, Kherson region.

Thus, we have established that microbiological parameters of snails' meat are directly proportional to the factors of the environment. The most favourable conditions to get clean products (meat, caviar) as well as mucus is the area in Berezna village, Polonsky district, Khmelnitsky region.

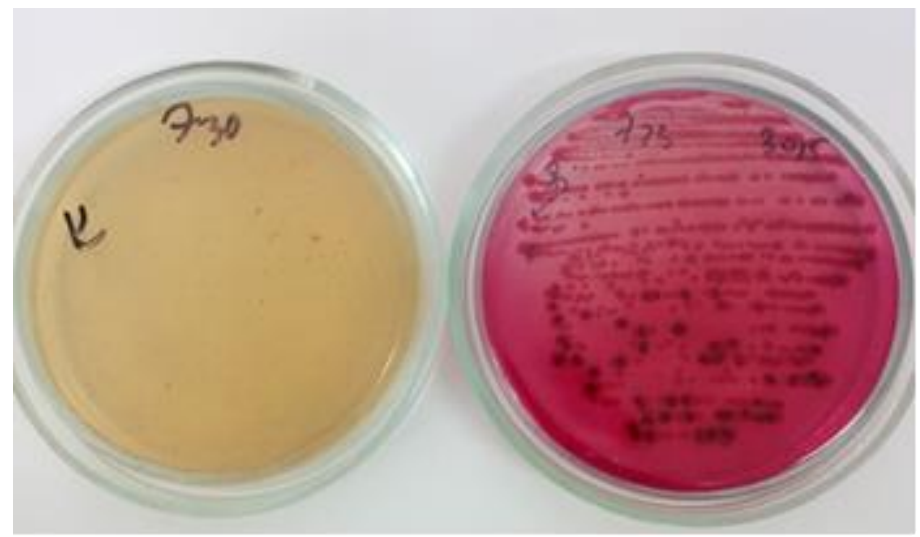

Figure 1. Growth of E. coli bacteria (coliforms) sample 3 (left-control, Endo environment, right-test, E. coli bacteria colony).

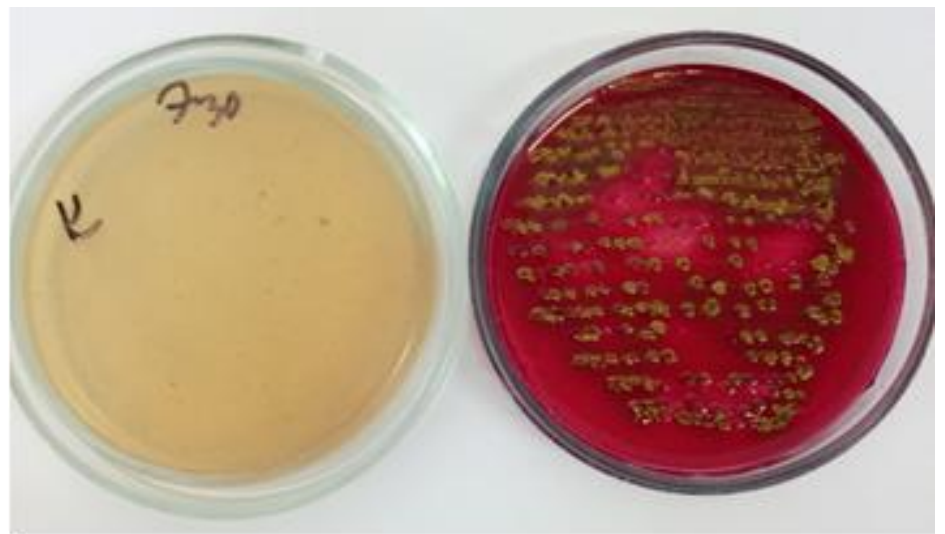

Figure 2. Growth of E. coli bacteria (coliforms) sample 2 (left-control, Endo environment, right-test, E. coli bacteria colony).

In the compulsory minimum list of research of raw materials, products of animal and vegetable origin, feed, mixed fodders, vitamin preparations, etc. which must be carried out in state veterinary medicine laboratories and according to the results of which veterinary certificate (F-2) (Order State Department of Veterinary Medicine of Ukraine №16 dated 1998.11.3.) is issued the data are given only for bivalve molluscs (live mussels, oysters and scallops) for which the maximum amount of MAOAM is not more than $5 \times 103$. If we compare these data with our findings we can conclude that snails' meat $H$. aspersa muller from the farm "RAVLYK 2016", snails' meat $H$. pomatia from Kazatske village, Berislavsky district, Kherson region and snails' meat $H$. pomatia from Mala Danylivka village, Dergachi district, Kharkiv region was not suitable for consumption at the time of research. Thus, it can be assumed that the environment caused a negative influence on the snails.

Factors of the environment that influence the development of microbes and vital functions of snails can be divided into three main groups: physical factors-moisture of the environment, concentration of dissolved substances in the medium and its osmotic pressure, temperature, various forms of radiation energy;

chemical factors-chemical composition and reaction of the environment, oxidation-restorative environmental conditions; biological factors-interaction of microorganisms with other organisms.

Temperature of the environment and even of the soil can be a powerful factor that influences the snails. Any fluctuations in the optimum temperature (norm-18-25 ${ }^{\circ} \mathrm{C}$ ) affect them negatively, but microbes in comparison to molluscs are more adapted to significant temperature fluctuations. Direct sunlight, drying, various forms of radiative energy have a harmful influence both on snails and bacteria. For snails breeding it is necessary to maintain soil and air moisture at the level of $70-80 \%$.

Various microorganisms can exist at different $\mathrm{pH}$ values of the environment which is not common for snails. The soil acidity 7.0 is optimal for them.

Numerous chemical substances cause poisonous effect both on snails and microbes. They include salts of heavy metals, acids, alkali, alcohols, essential oils, resins, etc. 
And biological factors-when the influence of microorganisms on the organism of snails is excessive, it causes first of all the reduction of their growth and development, affects the reproduction, and then leads to the death of molluscs.

\section{Conclusion}

Snails as raw materials are mostly seeded by different microflora. It can lead to the damage of products and reduction of permissible terms of their storage. Contamination of snails and therefore contamination of prepared products by microflora causes not only significant economic loss, but it can also lead to intoxication of people with poisonous substances and pathogenic bacteria that cause serious diseases which can be even dangerous for life. In cases of putrefaction signs of snails such products are considered unsuitable for consumption and in doubtful cases additional laboratory methods of research are used to define freshness of products.

For snails breeding it is necessary to minimize the negative influence of such environmental factors as air, soil and water. To achieve this aim it is necessary to use an area only for a snail enclosure, which should be located far from the roadway in order to avoid the permanent influence of dust and of microorganisms that can dissipate with air flow. There should be also an inclination to avoid puddles during the rain. Soil microbial contamination should be periodically determined. Water is an important component for the growth, development and movement of snails on the ground, therefore, it is necessary to use only a special water tower. This water should not contain chlorine and meet the relevant norms for drinking water.

In premises where snails are kept in the cold season the amount of dust, and therefore, microorganisms depends on the way of cleaning, organization of the production process, the application and effectiveness of ventilation, etc. At an enterprise or in a shop, as well as in places of storage of products, it is necessary to keep not only certain humidity and temperature of air, but also its purity. Wet cleaning of premises, systematic ventilation especially with the use of filtration of air reduces the dustiness of the premises significantly. In some cases, disinfection is carried out to clean the air from microorganisms with the use of only those disinfectants that are harmless to snails. To disinfect the air of workshops and refrigeration chambers ultra-violet radiation has been successfully used recently.

\section{References}

Masoumbeigi, H., Tavakoli, H. R., Koohdar, V., Mashak, Z., \& Qanizadeh, G. (2017). The environmental influences on the bacteriological quality of red and chicken meat stored in fridges. Asian Pacific Journal of Tropical Biomedicine, 7(4), 367-372. https://doi.org/10.1016/j.apjtb.2017.01.006

Koutsoumanis, K., Stamatiou, A., Skandamis, P., \& Nychas, G. J. (2006). Development of a microbial model for the combined effect of temperature and $\mathrm{pH}$ on spoilage of ground meat, and validation of the model under dynamic temperature conditions. Appl. Environ. Microbiol., 72(1), 124-134. doi: 10.1128/AEM.72.1.124-134.2006

Stella, S., Bernardi, C., \& Tirloni, E. (2018). Influence of skin packaging on raw beef quality: a review. Journal of Food Quality. https://doi.org/10.1155/2018/7464578

DSTU 8446:2015. Food products. Methods of determining the amount of mesophilic aerobic and optional anaerobic microorganisms.

GOST 30518-97. Food products. Methods of detection and determination of the number of bacteria in the group of intestinal sticks (coliform bacteria).

GOST 10444.2-94. Food products. Methods for detecting and quantifying Staphylococcus aureus.

DSTU 7444:2013. Food products. Methods for detecting bacteria of the genera Proteus, Morganella, Providencia.

DSTU EN 12824:2004. Microbiology of food and animal feed Hormonal detection method of Salmonella.

DSTU ISO 11290-1:2003. Microbiology of food and animal feed. Horizontal method for detecting and counting Listeria monocytogenes. Part 1. Detection method.

DSTU ISO 11290-2:2003. Microbiology of food and animal feed. Horizontal method for detecting and counting Listeria monocytogenes. Part 2. Method of calculation.

Order State Department of Veterinary Medicine of Ukraine №16 dated 1998.11.3. on approval of a mandatory minimum list of research on raw materials, products of animal and plant origin, feed, fodder, vitamin products, etc. carry out in state veterinary laboratories and on the basis of which the veterinary certificate (F-2) is issued.

Mitichkin, G. S. (1966). Microbiology of meat. Moscow.

Klevakin, V. M., Kartsev, V. V. (1986). Sanitary microbiology of food L. Medicine.

Mikityuk, P. V., Zhitenko, P. V., \& Osetrov, V. S. (1989). Veterinary-sanitary examination of freshwater fish: Reference book M. Agropromizdat.

Citation: Danilova, I., Danilova, T. (2019). The influence of the environment on microbiological parameters of snails' meat. Ukrainian Journal of Ecology, 9(3), 3740. 